\title{
STRATEGI INDEX CARD MATCH UNTUK PENINGKATAN PEMAHAMAN SISWA SMK MATA PELAJARAN PKn
}

\author{
Oleh: \\ Ahmad Nasir Ari Bowo \\ Universitas Cokroaminoto Yogyakarta
}

\begin{abstract}
Abstrak
Proses pembelajaran di kelas pasti ada masalah yang dihadapi oleh seorang guru. Dasar Negara dan Hubungan Konstitusi merupakan salah satu materi dalam mata pelajaran Pendidikan Kewarganegaraan. Kemampuan siswa dalam memahami materi ini sangat kurang. Jumlah siswa SMK Negeri 2 Purwodadi kelas X TKB 1 berisi 33 siswa. Dari jumlah tersebut hanya 13 siswa saja yang aktif dalam mengikuti materi Dasar Negara dan Hubungan Konstitusi, sisanya bersikap pasif yaitu 20 orang. Tentunya hal tersebut menyisakan suatu permasalahan yang harus segera diselesaikan.

Hasil observasi dan refleksi pada tindakan kelas siklus II dievaluasi bersama guru kelas. Maka dari itu diperoleh tindakan pembelajaran yang dilakukan oleh guru bersama peneliti yang sesuai dengan harapan yaitu: 1) Pemahaman peserta didik dalam pembelajaran mengalami peningkatan yang cukup baik. 2) Pemahaman peserta didik dalam mengikuti pembelajaran meningkat, dilihat dari hasil penilaian tugas yang dilakukan oleh peneliti. 3) Hasil belajar peserta didik mengalami peningkatan $(62,06 \%$ $86,20 \%$ ) yang sangat berarti, ini terlihat pada hasil nilai siklus yang semakin meningkat. 4) Pembelajaran dengan strategi Index Card match dapat meningkatkan $(86,20 \%)$ pe-mahaman peserta didik dalam materi kedaulatan rakyat dan sistem pemerintahan Indonesia. 5) Berdasarkan pembelajaran secara keseluruhan dari tindakan kelas siklus I sampai berakhirnya siklus II, usaha untuk mengatasi permasalahan yaitu rendahnya kemampuan siswa dalam memahami materi kedaulatan rakyat dan sistem pemerintahan Indonesia sudah mengalami perubahan yang positif.
\end{abstract}

Kata Kunci: Strategi, Indek Card Match, Pemahaman, Siswa SMK

\section{Pendahuluan}

Saat pelajaran di kelas semua siswa diharapkan untuk ikut aktif dalam proses pembelajaran. Dengan demikian maka siswa akan lebih mudah untuk memahami materi yang akan disampaikan guru mata pelajaran PKn di kelas. Kurangnya pemahaman siswa SMK Negeri 2 Purwodadi kelas X TKB 1 dalam mengikuti materi Dasar Negara dan Hubungan Konstitusi akan berdampak pada kurangnya pemahaman siswa terhadap materi tersebut. Dengan demikian apa yang menjadi tujuan dari materi pelajaran tersebut akan sulit tercapai. Untuk memecahkan permasalahan tersebut guru sudah mencoba beberapa metode, diantaranya adalah metode ceramah, ular tangga, dan diskusi. Akan tetapi metode tersebut belum mampu untuk meningkatkan pemahaman siswa pada materi Dasar Negara dan Hubungan Konstitusi. 
Oleh karena itu perlu dilakukan langkah alternatif lain yang diharapkan mampu meningkatkan pemahaman siswa pada materi pelajaran Dasar Negara dan Hubungan Konstitusi. Untuk itu penulis mengajukan strategi Index Card Match sebagai upaya meningkatkan pemahaman siswa pada materi pelajaran Dasar Negara dan Hubungan Konstitusi. Dengan metode ini mau tidak mau semua siswa dipaksa untuk ikut aktif terkait materi pelajaran yang dipelajari. Dengan demikian cara ini diharapkan pe-mahaman siswa dalam mengikuti pelajaran dapat meningkat. Berdasarkan latar belakang masalah di atas, penulis tertarik untuk mengadakan penelitian tindakan kelas tentang "Peningkatan Pemahaman Materi Dasar Negara dan Hubungan Konstitusi Melalui Penerapan Strategi Index Card Match dalam Pem-belajaran PKn pada Siswa Kelas X TKB 1 SMK Negeri 2 Purwodadi Tahun Pelajaran 2010/2011”.

Perumusan masalah merupakan bagian terpenting yang harus ada dalam penulisan karya ilmiah. Oleh karenanya, sebelum melakukan penelitian, harus mengetahui terlebih dahulu permasalahan yang ada. Dengan permasalahan yang jelas maka proses pemecahannya akan terarah dan terfokus. Berdasarkan latar belakang permasalahan di atas maka dapat dirumuskan suatu permasalahan "Apakah Penerapan Strategi Pembelajaran Index Card Match dapat Meningkatkan Pemahaman Materi Dasar Negara dan Hubungan Konstitusi dalam Pembelajaran PKn pada Siswa Kelas X TKB 1 SMK Negeri 2 Purwodadi Tahun Pelajaran 2010/2011”? Adapun tujuan penelitian ini adalah untuk meningkatkan penguasaan materi siswa dalam proses pembelajaran Pendidikan Kewarganegaraan, untuk meningkatkan prestasi belajar siswa dalam pembelajaran Pendidikan Kewarganegaraan, untuk meningkatkan ketercapaian kriteria kelulusan minimal, dan meningkatkan pemahaman materi Dasar Negara dan Hubungan Konstitusi dalam pembelajaran PKn melalui penerapan strategi Index Card Match pada siswa kelas X TKB 1 SMK Negeri 2 Purwodadi Tahun Pelajaran 2010/2011.

\section{Kajian Teori}

Penyampaian materi pelajaran di kelas mempunyai permasalahan yang sangat bervariasi. Setiap siswa dalam satu kelas mempunyai kemampuan yang berbeda-beda. Mulai dari tingkat kecerdasan sampai dengan cara berperilaku dalam kelas. Per-masalahan yang ada saat ini adalah kurangnya pemahaman siswa pada materi pelajaran Dasar Negara dan Hubungan Konstitusi. Untuk itulah penelitian ini mencoba untuk mengajukan metode pembelajaran kooperatif untuk mengatasi permasalahan tersebut diantaranya: 


\section{a. Pengertian Index Card Match.}

Menurut Silberman (2001:79) index card match adalah: "Cara menyenangkan lagi aktif untuk meninjau ulang materi pelajaran. Ia membolehkan peserta didik untuk berpasangan dan memainkan kuis dengan kawan sekelas". Menurut Zaini dkk (2002:64) menjelaskan bahwa, index card match adalah: "Strategi yang cukup menyenangkan yang digunakan untuk mengulang materi yang telah diberikan sebelumnya".

b. Kebaikan Strategi Pembelajaran Index Card Match.

Menurut Suyanto (2010:14). Kebaikan strategi index card match adalah sebagai berikut:

1) Meningkakatn partisipasi anak.

2) Cocok untuk tugas sederhana.

3) Lebih banyak kesempatan untuk konstribusi masing-masing anggota kelompok.

4) Interaksi lebih mudah.

5) Lebih mudah dan cepat dalam membentuk kelompok.

c. Kelemahan Strategi Pembelajaran Index Card Match.

Menurut Suyanto (2010:14). Kelemahan strategi index card match adalah:

1) Banyak kelompok yang melapor dan perlu dimonitor,

2) Lebih sedikit ide yang muncul.

3) Jika ada perselisihan tidak ada penengah.

d. Langkah-Langkah Pelaksanaan Strategi Pembelajaran Index Card Match.

Menurut Hisyam Zaini, dkk (2002:64-65). Langkah-langkah pelaksanaan strategi index card match adalah sebagai berikut:

1) Buat potongan-potongan kertas sebanyak jumlah siswa yang ada dalam kelas.

2) Bagi kertas-kertas tersebut menjadi dua bagian yang sama.

3) Pada separuh bagian, tulis pertanyaan tentang materi yang akan diajarkan. Setiap kertas berisi satu pertanyaan.

4) Pada separuh kertas yang lain, tulis jawaban dari pertanyaan yang tadi dibuat.

5) Kocoklah semua kertas sehingga akan tercampur antara soal dan jawaban.

6) Setiap siswa diberi satu kertas. Jelaskan bahwa ini adalah aktifitas yang dilakukan berpasangan. Separuh siswa akan mendapatkan jawaban. 
7) Minta siswa untuk menemukan pasangan mereka. Jika ada yang sudah menemukan pasangan, minta mereka untuk duduk berdekatan. Terangkan juga agar mereka tidak memberitahu materi yang mereka dapatkan kepada teman yang lain.

8) Setelah semua menemukan pasangan dan duduk berdekatan, minta setiap pasangan secara bergantian untuk membacakan soal yang diperoleh dengan keras kepada teman-teman yang lain. Selanjutnya soal tersebut dijawab oleh pasangannya.

9) Akhiri proses ini dengan membuat klarifikasi dan kesimpulan.

Dari pengertian di atas maka dapat disimpulkan strategi pembelajaran index card match adalah strategi pembelajaran yang dipilih guru untuk me-nyampaikan materi pelajaran dengan cara yang menyenangkan lagi aktif untuk meninjau ulang materi pelajaran yang telah diberikan sebelumnya. Guru juga membolehkan peserta didik untuk berpasangan dan memainkan kuis dengan kawan sekelas. Cara memain-kan kuis tersebut dapat dilakuakan secara bervariasi disesuaikan dengan keadaan yang ada.

Hasil penelitian Budiyanto dkk (2009:55) membuktikan, bahwa: strategi kartu indeks ini dapat diterapkan untuk pembelajaran IPS karena terbukti dapat meningkatkan penilaian aspek penguasaan konsep. Hasil penelitian Suwardiyana dkk (2009:41) membuktikan, bahwa: dengan menggunakan strategi pembelajaran index card match dapat meningkatkan motivasi belajar siswa, yang ditandai de-ngan antusiasme partisipasi siswa dalam mengikuti pembelajaran di kelas dan dapat dilihat pula dari hasil evaluasi dimana prosentase perolehan nilai yang sudah mencapai KKM mencapai $80 \%$. Berdasarkan hasil penelitian di atas metode yang digunakan merupakan metode pembelajaran kooperatif, telah terbukti mampu meningkatkan pemahaman siswa dalam mengikuti pelajaran. Oleh karena itu, sangat beralasan untuk diada-kan kajian mengenai "Peningkatan Pemahaman Materi Dasar Negara dan Hubungan Konstitusi Melalui Penerapan Strategi Index Card Match dalam Pembelajaran PKn, sebagai-mana fokus penelitian.

Berdasarkan kajian teoritis sebagaimana telah dipaparkan di atas, maka dalam penelitian ini dipandang perlu mengajukan kerangka pemikiran sebagai berikut:

1. Penerapan index card match akan mampu meningkatkan pemahaman siswa pada waktu mengikuti materi pelajaran Dasar Negara dan Hubungan Konstitusi.

2. Adanya keterkaitan antara penerapan strategi pembelajaran index card match dengan peningkatan pemahaman siswa pada materi Dasar Negara dan Hubungan Konstitusi. 
Bila digambarkan maka akan tampak kerangka pemikiran sebagaimana gambar siklus berikut ini.

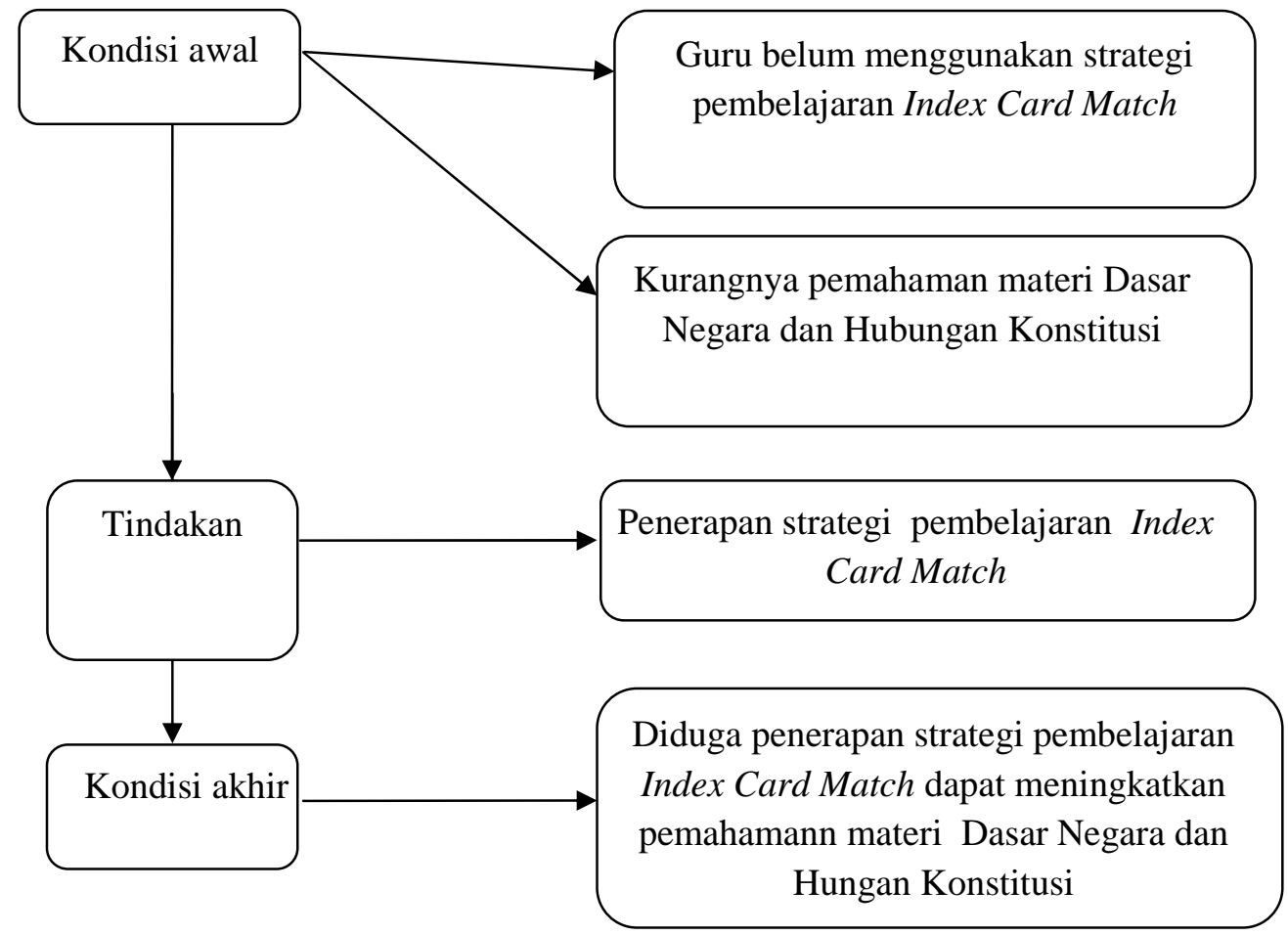

Gambar 1. Siklus Kerangka Pemikiran

Hipotesis yang akan diajukan oleh peneliti adalah "Diduga dengan Penerapan Strategi Pembelajaran Index Card Match dapat Meningkatkan Pemahaman Materi Dasar Negara dan Hubungan Konstitusi dalam Pembelajaran PKn pada Siswa Kelas X TKB 1 SMK Negeri 2 Purwodadi Tahun Pelajaran 2010/2011".

\section{Metode Penelitian}

Tempat penelitian ini adalah di SMK Negeri 2 Purwodadi Tahun Pelajaran 2010/2011. Pemilihan tempat tersebut di dasarkan pada pertimbangan (1) Lokasi dekat dengan tempat tinggal peneliti, (2) mudah untuk memperoleh data-data yang di-butuhkan, (3) komunikasi dengan pihak sekolahan relatif mudah. Penelitian ini berlangsung selama 4 bulan, yaitu bulan Maret sampai dengan Juni 2011. Subyek penelitian tindakan ini adalah siswa dan guru PKn SMK Negeri 2 Purwodadi. Siswa yang dijadikan subyek penelitian ini adalah siswa kelas X TKB 
1. Siswa kelas tersebut berjumlah 33 orang. Sementara itu, guru yang dijadikan subjek penelitian ini adalah guru kelas X TKB 1 .

Adapun prosedur penelitian Menurut Arikunto (2006:16-20) model penelitian tindakan kelas adalah: "secara garis besar terdapat empat tahapan yang harus dilalui, yaitu (1) perencanaan (2) pelaksanaan, (3) pengamatan, (4) refleksi”.

Adapun model dan penjelasan untuk masing-masing tahapan adalah sebagai mana bagan berikut ini.

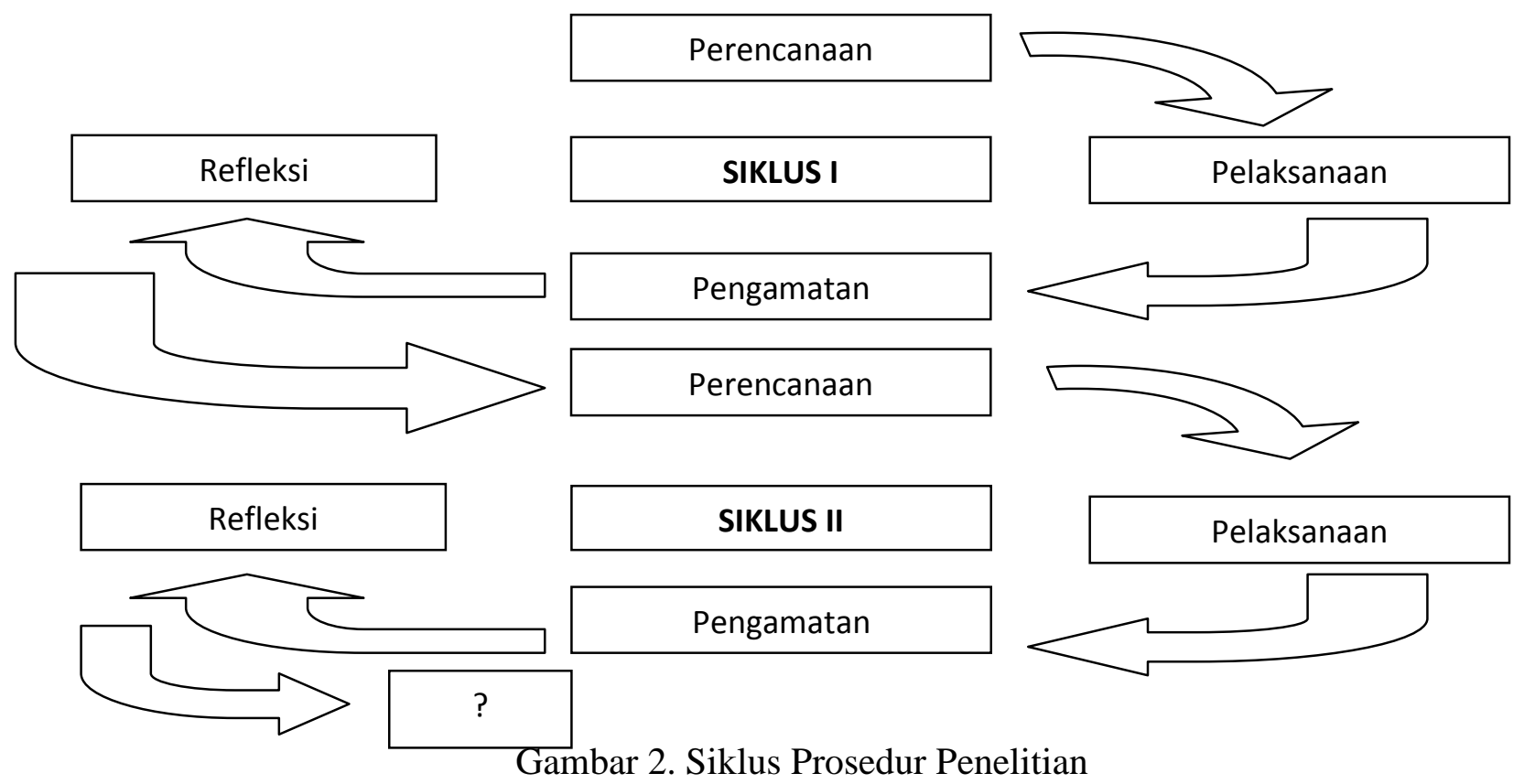

\section{Hasil Penelitian dan Pembahasan}

\section{Kondisi Awal Kelas X TKB 1 SMK Negeri 2 Purwodadi}

Dasar Negara dan Hubungan Konstitusi merupakan salah satu materi pelajaran PKn kelas X TKB 1 Semester II. Jumlah siswa kelas X TKB 1 SMK Negeri 2 Purwodadi dalam satu kelas berisi 33 siswa. Dari jumlah tersebut hanya 13 siswa atau 39,39\% yang paham dalam mengikuti pelajaran PKn materi Dasar Negara dan Hubungan Konstitusi. Jadi masih ada 20 siswa atau 60,61\% yang kemampuan memahami materi Dasar Negara dan Hubungan Konstitusi masih kurang. Secara lebih rinci daftar pemahaman siswa kelas X TKB 1 SMK Negeri 2 Purwodadi dapat dilihat pada tabel di bawah ini. 
Tabel 2. Daftar Pemahaman Siswa Kelas X TKB 1 SMK Negeri 2 Purwodadi Sebelum pelaksanaan strategi Index Card Match

\begin{tabular}{|c|c|c|}
\hline No & Pemahaman Siswa & Banyak (prosentase) \\
\hline 1 & Pemahaman penguasaan materi & 4 Siswa $(12,12 \%)$ \\
\hline 2 & Pemahaman mengemukakan pendapat atau ide. & 5 Siswa $(15,15 \%)$ \\
\hline 3 & Pemahaman mengerjakan soal & 4 Siswa $(12,12 \%)$ \\
\hline & Jumlah Total & 13 Siswa $(39,39 \%)$ \\
\hline
\end{tabular}

Sumber: Hasil wawancara dengan guru kelas X TKB 1

Kurangnya Pemahaman siswa dalam mempelajari materi Dasar Negara dan Hubungan Konstitusi, secara tidak langsung akan mempengaruhi prestasi belajar yang hendak dicapai. Jumlah siswa kelas X TKB 1 SMK Negeri 2 Purwodadi dalam satu kelas berisi 33 siswa, dari jumlah tersebut hanya 13 siswa atau 39,39\% yang paham dalam mengikuti pelajaran PKn materi Dasar Negara dan Hubungan Konstitusi, baik dalam penguasaan materi, mengemukakan pendapat, dan mengerjakan soal. Dengan demikian apa yang menjadi tujuan materi pelajaran tersebut akan sulit tercapai. Maka solusi alternatif yang ditawarkan oleh peneliti adalah menerapkan strategi Index card Match. Alasan dipilihnya strategi Index Card Math karena strategi ini memiliki beberapa kelebihan dibandingkan dengan strategi lainya. Kelebihan strategi pembelajaran ini antara lain siswa akan lebih aktif dan paham dalam mengikuti pelajaran, karena setiap siswa akan terlibat langsung dalam mempresentasikan salah satu kategori yang berisi informasi yang mencakup materi yang sudah disampaikan. Dengan demikian pemahaman siswa kelas X TKB 1 dalam pembelajaran dapat meningkat.

\section{Dialog Awal}

Penelitian mulai dilaksanakan pada bulan Maret 2011, diawali dengan dialog peneliti, guru PKn kelas X TKB 1. Selanjutnya peneliti dan guru sebagai mitra melakukan dialog untuk mengetahui permasalahan yang ada pada kelas tersebut. Berdasarkan pengalaman guru dalam mengajar materi Dasar Negara dan Hubungan Konstitusi dan mengamati secara langsung di kelas, maka guru Pkn menyimpulkan permasalahan yang ada pada kelas X TKB 1 adalah rendahnya pemahaman pada materi Dasar Negara dan Hubungan Konstitusi. Setelah kegiatan 
merumuskan masalah di atas, dilanjutkan dengan mengidentifikasikan faktor-faktor penyebab masalah. Hasil kerja antara guru mata pelajaran PKn kelas X TKB 1 dan peneliti disepakati bahwa asumsi penyebab masalah kurangnya pemahaman dalam pembelajaran yaitu pasif dalam menerima informasi, kurangnya minat belajar siswa, semangat belajar siswa,konsentrasi. Masalah lain yang menyebabkan kurangnya pemahaman siswa karena pembelajaran hanya berpusat pada guru dan dalam menyampaikan materi ajar atau informasi kurang variatif. Berdasarkan berbagai kemungkinan penyebab masalah yang dijelaskan di atas kemudian dapat diambil sebuah kesimpulan bahwa penyebab masalah yang paling dominan adalah pasif dalam menerima informasi dan sulit mengutarakan ide tau pendapat, sehingga berpusat pada guru dalam pembelajaran. Berdasarkan kesimpulan mengenai faktor-faktor penyebab tersebut kemudian dilakukan diskusi guna merumuskan solusi dan rancangan kegiatan yang perlu dilakukan. Pembahasan perencanaan solusi masalah ini dilakukan dalam satu rangkaian dialog awal kedua yaitu Sabtu, 19 Maret 2011. Tindakan solusi masalah yang ditawarkan dalam penelitian ini yaitu melalui penerapan strategi Index Card Match sebagai upaya meningkatkan pemahaman siswa dalam pembelajaran PKn pada materi Dasar Negara dan Hubungan Konstitusi. Tindakan pembelajaran dengan penerapan strategi Index Card Match akan diterapkan pada siswa kelas X TKB 1 dan dikembangkan pada setiap siklus tindakan melalui perencanaan yang terevisi. Penerapan strategi Index Card Match diharapkan dapat mengubah pembelajaran yang semula siswa hanya pasif menjadi lebih aktif dalam bertanya maupun berpendapat serta menjawab pertanyaan dengan baik. Selanjutnya pembelajaran yang semula hanya berpusat pada guru akan berubah menjadi pembelajaran yang berpusat pada siswa dan guru hanya sebagai fasilitator saja.

3. Identifikasi Masalah dan penyebabnya

Peneliti merumuskan permasalahan siswa sebagai upaya untuk meningkat-kan pemahaman siswa khususnya pada mata pelajaran Dasar Negara dan Hubungan Konstitusi. Tindakan yang diterapkan pada identifikasi masalah antara lain:

a) Penerapan strategi pengajaran yaitu strategi index card match .

b) Bagaimana menyikapi pemahaman siswa pada materi Dasar Negara dan Hubungan Konstitusi? 
c) Bagaimana mengusahakan siswa untuk aktif dalam proses pembelajaran pada mata pelajaran Dasar Negara dan Hubungan Konstitusi?

4. Perencanaan Tindakan

Berdasarkan hasil serangkaian kegiatan pada dialog awal, terlihat bahwa pembelajaran PKn belum dapat dilaksanakan dengan baik sehingga hasil belajar yang dicapai siswa belum optimal. Hasil kesepakatan guru dan peneliti, tindakan yang akan dilakukan yaitu penerapan strategi Index Card Match meningkatkan pemahaman materi Dasar Negara dan Hubungan Konstitusi dalam pembelajaran $\mathrm{PKn}$. Sebelum tindakan pembelajaran, program tindakan pembelajaran dilakukan peneliti sendiri dengan merancang pengembangan silabus, rancangan perencanaan pembelajaran guru (RPP) dan pembagian segmen materi untuk masing-masing individu yang akan disampaikan pada siswa pada setiap siklusnya.

\section{Análisis Pencarian Fakta}

Tindakan dilaksanakan sesuai dengan isi rancangan pembelajaran dan menerapkan rancangan tindakan yang telah disusun berdasarkan permasalahan yang diduga mempengaruhi pembelajaran PKn dan berakibat pada kurangnya pemahaman siswa dalam pembelajaran PKn materi Dasar Negara dan Hubungan Konstitusi pada siswa kelas X TKB 1 SMK Negeri 2 Purwodadi. Peneliti melaksanakan tindakan pembelajaran pada kelas X TKB 1 dengan berpedoman pada rencana pelaksanaan pembelajaran dan perencanaan tindakan kelas yang disusun sebelum pelaksanaan tindakan. Rencana pelaksanaan pembelajaran (RPP) disusun oleh peneliti yang dikonsultasikan dengan guru kelas sebagai mitra kolaborasi. Pelaksanaan tindakan penelitian dilakukan oleh peneliti sendiri dengan didampingi guru kelas X TKB 1 SMK Negeri 2 Purwodadi Bapak Moh Ali Munawar S.Pd M.M.

\section{Tindakan Kelas Siklus I}

Tindakan kelas siklus I merupakan langkah awal dalam pelaksanaan penelitian tindakan kelas. Langkah ini terdiri dari beberapa tahap antara lain sebagai berikut:

a. Perencanaan Siklus I

Strategi pembelajaran yang digunakan pada siklus I adalah strategi Index Card Martch. Materi ajar yang disampaikan ádalah Dasar Negara dan Hubungan Konstitusi. Alokasi waktunya 2 jam pelajaran @ 45 menit dan di-distribusikan ke dalam satu rencana pembelajaran. Berarti 
tindakan kelas siklus I terbagi dalam 1 kali pertemuan di kelas. Pembelajaran pada siklus I membahas materi Dasar negara dan Hubungan Konstitusi yang terdiri dari beberapa sub pokok materi yaitu: unsur konstitusi, negara, macam-macam konstitusi negara, ciri konstitusi bagi negara tertentu, substansi konstitusi indonesia. Tindakan pembelajaran yang dilakukan adalah:

1) Peneliti mendampingi guru sebagai rekan kolaborasi dalam melaksanakan proses pembelajaran mata pelajaran PKn.

2) Guru sebagai rekan kolaborasi menyampaikan tujuan pelajaran secara umum.

3) Guru sebagai rekan kolaborasi menjelaskan materi ajar sesuai dengan pokok bahasan.

4) Guru sebagai rekan kolaborasi membagi satu kartu indeks kepada setiap peserta didik, sebagian peserta didik memegang pertanyaan dan sebagian lagi memegang jawaban.

5) Guru sebagai rekan kolaborasi memberikan perintah kepada peserta didik untuk menemukan kartu pasangannya, ketika peserta didik sudah menemukan pasangannya guru meminta peserta didik untuk mencari tempat duduk bersama (beritahu mereka jangan menyatakan kepada peserta didik lain apa yang ada pada kartunya).

6) Ketika semua peserta didik sudah menemukan pasanganya dan telah menempati tempatnya, guru memberikan perintah agar setiap pasangan menguji peserta didik yang lain dengan membaca keras pertanyaannya dan menantang teman sekelas untuk menginformasikan jawaban kepadanya.

b. Hasil Tindakan Siklus I

1) Observasi dan Monitoring Tindakan Kelas Siklus I

a) Proses pembelajaran

Proses pembelajaran pada siklus I dilaksanakan dalam satu putaran. Awal putaran dimulai dengan penyampaikan tujuan dan motivasi dari guru kepada siswa. Setelah itu guru dan peneliti membagikan satu kartu kepada peserta didik, dimana sebagian peserta didik memegang nama kategori dan sebagian lagi memegang jawabannya. Pelaksanaan siklus pertama sedikit mengalami hambatan. Pada awal putaran pertama masih banyak siswa yang ramai sendiri. Para siswa pada umumnya masih bingung, kemudian guru memberikan arahan tentang pelaksanaan strategi Index Card Match agar siswa lebih paham. Setelah mendapatkan arahan dari guru siswa mulai dapat menjalankan permainan mencari pasangan dengan baik walaupun belum maksimal. 
Guru memberikan perintah kepada peserta didik untuk menemukan kartu pasangannya, ketika peserta didik sudah menemukan pasangannya guru meminta peserta didik untuk mencari tempat duduk bersama (beritahu mereka jangan menyatakan kepada peserta didik lain apa yang ada pada kartunya). Ketika semua peserta didik sudah menemukan pasangannya dan telah menempati tempatnya, guru memberikan perintah agar setiap pasangan menguji peserta didik lain dengan membaca keras kategori dan pasangan jawabannya. Di akhir pembelajaran peserta didik diminta untuk mengerjakan soal-soal yang sudah disediakan oleh guru dan peneliti, dimana dari soal-soal itu akan mengetahui apakah peserta didik sudah dapat memahami materi yang telah dilaksanakan dalam proses pembelajaran pada siklus I.

b) Pemahaman peserta didik.

Pemahaman peserta didik pada siklus I masih kurang, hal ini dapat dilihat dari hasil penilaian tugas yang dilakukan oleh peneliti. Hasil pelaksanaan strategi

Index Card Match dalam proses pembelajaran adalah siswa yang paham terhadap materi sebanyak 18 (62,06\%) siswa. Berdasarkan hasil pelaksanaan tersebut dapat dilihat bahwa jumlah siswa yang memiliki kemampuan dalam memahami materi kedaulatan rakyat dan sistem pemerintahan Indonesia masih kurang. Oleh karena itu maka target dari penggunaan strategi Index Card Match belum tercapai.

\section{c. Refleksi Siklus I}

Pada akhir putaran pertama guru masih memberikan banyak penjelasan ten-tang materi dan arahan tentang pelaksanaan strategi Index Card Match, karena siswa pada umumnya masih bingung. Berdasarkan kegiatan refleksi diperoleh beberapa hal yang dapat dicatat sebagai masukan untuk perbaikan pada tindakan selanjutnya, yaitu:

a. Guru perlu mengatur waktu pelaksanaan pembelajaran dengan menggunakan strategi Index Card Match dengan baik.

b. Keadaan kelas masih gaduh saat pelajaran berlangsung.

c. Kerjasama antar peserta didik masih kurang sehingga masih dibutuhkan perbaikan-perbaikan.

d. Masih banyak peserta didik yang tidak memperhatikan pada saat diterapkannya strategi Index Card Match. 
Berdasarkan hasil refleksi terhadap tindakan kelas siklus I, maka rencana tindakan kelas siklus I perlu direvisi dan hasilnya akan digunakan sebagai acuan dalam pelaksanaan tindakan kelas siklus II, berbagai revisi yang disepakati rekan kolaborasi adalah sebagai berikut:

a) Pada setiap pertemuan, pengajar atau peneliti perlu mengoptimalkan persepsi untuk memberikan motivasi baik penggabungan materi atau dorongan untuk meningkatkan pemahaman belajar peserta didik.

b) Pembuatan kartu pembelajaran diupayakan lebih menarik minat siswa untuk mengikuti pembelajaran dengan senang dan gembira, sehingga siswa lebih aktif dalam mengikuti pelajaran

c) Pembelajaran harus berpusat pada peserta didik.

d) Guru harus lebih banyak menerapkan pembelajaran dengan metode Index Card Match.

e) Pengoptimalan pembelajaran dengan metode Index Card Match pada materi Dasar Negara dan Hubungan Konstitusi . Hal ini dapat dilakukan dengan cara menyesuaikan materi dengan jam pelajaran, sehingga siswa lebih nyaman dalam mengikuti pelajaran dan hasilnya dapat tercapai dengan maksimal.

\section{Tindakan Kelas Siklus II}

1) Perencanaan siklus II

Perencanaan tindakan kelas siklus II yang berkaitan dengan pembelajaran putaran I telah direvisi. Pembelajaran pada siklus II membahas materi sistem pemerintahan Indonesia dan peran lembaga negara sebagai pelaksana kedaulatan rakyat yang terdiri dari beberapa sub pokok materi antara lain: sistem pemerintahan Indonesia, peran lembaga negara sebagai pelaksana kedaulatan rakyat. Alokasi waktunya 1 jam pelajaran @ 40 menit, tindakan kelas siklus II dilaksanakan dalam satu kali pertemuan.

2) Hasil tindakan kelas siklus II

1) Hasil observasi dan monitoring tindakan kelas siklus II.

a) Proses Pembelajaran

Proses pembelajaran pada siklus II dilaksanakan dalam satu putaran. pada awal putaran ini secara umum siswa sudah memahami proses pelaksanaan strategi Card Sort dengan baik. Setelah itu guru dan peneliti langsung membagikan satu kartu kepada peserta didik, dimana sebagian 
peserta didik memegang pertanyaan dan sebagian lagi memegang jawabannya. Guru memberikan perintah kepada peserta didik untuk menemukan kartu pasangannya, ketika peserta didik sudah menemukan pasangannya guru meminta peserta didik untuk mencari tempat duduk bersama (beritahu mereka jangan menyatakan kepada peserta didik lain apa yang ada pada kartunya). Ketika semua peserta didik sudah menemukan pasangannya dan telah menempati tempatnya, guru memberikan perintah agar setiap pasangan menguji peserta didik lain dengan membaca keras nama kategori dan jawabannya. Di akhir pembelajaran peserta didik diminta untuk mengerjakan soal-soal yang sudah disediakan oleh guru dan peneliti, dimana dari soal-soal itu akan mengetahui apakah peserta didik sudah dapat memahami materi yang telah dilaksanakan dalam proses pembelajaran pada siklus II.

Penggunaan strategi Card Sort berjalan dengan lancar, susana kelas sangat kondusif. Para siswa berkonsenstrasi penuh membaca kalimat pada kartu dan mencari pasangannya dan saat mengerjakan soal-soal yang diberikan oleh guru. Selama proses pembelajaran peneliti melakukan pemantauan pada siswa yang berusaha mencari pasangannya dan saat peserta didik menjawab soal-soal. Secara umum proses pembelajaran dengan menggunakan strategi Card Sort berjalan dengan baik.

b) Pemahaman peserta didik

Pemahaman peserta didik pada siklus II ada peningkatan dibandingkan siklus I, hal ini dapat dilihat dari hasil penilaian tugas yang dilakukan oleh peneliti. Hasil pelaksanaan strategi Card Sort dalam proses pembelajaran adalah siswa yang paham terhadap materi meningkat sebanyak 25 (86,20\%) siswa. Berdasarkan hasil pelaksanaan tersebut dapat dilihat bahwa jumlah siswa yang memiliki kemampuan dalam memahami materi kedaulatan rakyat dan sistem pemerintahan Indonesia mengalami peningkatan yang cukup signifikan. Peningkatan yang terjadi pada siklus II sudah baik walaupun belum mencapai target yang diinginkan, yaitu sebesar $85 \%$ dari 29 siswa.

\section{3) Refleksi tindakan kelas siklus II}

Kegiatan refleksi ini mendiskusikan hasil observasi tindakan kelas siklus II. Refleksi dilakukan bersama guru PKn dengan peneliti dan dilakukan pada hari Kamis, 27 Mei 2010 pada pukul 08.20 - 09.40 WIB. Kegiatan refleksi ini di-laksanakan oleh peneliti bersama guru 
pelajaran PKn sebagai mitra kolaborasi. Refleksi ini mendiskusikan hasil observasi tindakan yang dilakukan, dan hasil refleksi diperoleh beberapa kesepakatan antara lain:

1) Pembelajaran pada tindakan kelas siklus II jauh lebih baik dibanding pada siklus I.

2) Jumlah siswa yang paham meningkat menjadi $86,20 \%$.

3) Kemampuan siswa dalam memahami materi pelajaran kedaulatan rakyat dan sistem pemerintahan Indonesia meningkat terlihat dari hasil penilaian tugas yang dilakukan oleh peneliti.

4) Pembelajaran dengan strategi Card Sort belum dapat diterapkan secara optimal dikarenakan kurangnya persiapan.

Berdasarkan pembelajaran secara keseluruhan dari tindakan kelas siklus I sampai berakhirnya siklus II, usaha untuk mengatasi permasalahan yaitu rendahnya kemampuan siswa dalam memahami materi kedaulatan rakyat dan sistem pemerintahan Indonesia sudah mengalami perubahan yang positif. Maka dari itu perlu diadakan pengembangan penerapan strategi Card Sort bervariasi terhadap materi pelajaran yang lain, sehingga kemampuan siswa dapat lebih merata. Hasil observasi dan refleksi pada tindakan kelas siklus II dievaluasi bersama guru kelas. Maka dari itu diperoleh tindakan pembelajaran yang dilakukan oleh guru bersama peneliti yang sesuai dengan harapan yaitu:

1) Pemahaman peserta didik dalam pembelajaran mengalami peningkatan yang cukup baik.

2) Pemahaman peserta didik dalam mengikuti pembelajaran meningkat, dilihat dari hasil penilaian tugas yang dilakukan oleh peneliti.

3) Hasil belajar peserta didik mengalami peningkatan $(62,06 \%$ - 86,20\%) yang sangat berarti, ini terlihat pada hasil nilai siklus yang semakin meningkat.

4) Pembelajaran dengan strategi Index Card match dapat meningkatkan $(86,20 \%)$ pe-mahaman peserta didik dalam materi kedaulatan rakyat dan sistem pemerintahan Indonesia.

Berdasarkan pembelajaran secara keseluruhan dari tindakan kelas siklus I sampai berakhirnya siklus II, usaha untuk mengatasi permasalahan yaitu rendahnya kemampuan siswa dalam memahami materi kedaulatan rakyat dan sistem pemerintahan Indonesia sudah mengalami perubahan yang positif. 


\section{Kesimpulan}

Pada rangkaian putaran penelitian tindakan kelas yang telah dilakukan terlihat adanya perubahan yang merupakan hasil penelitian dalam rangka usaha meningkatkan pemahaman siswa dalam materi Dasar Negara dan Hubungan Konstitusi. Bertitik tolak dari tindakan yang telah dilaksanakan pada penelitian ini, maka dapat diambil beberapa kesimpulan sebagai berikut:

3. Penerapan strategi Index Card Match telah mampu meningkatkan pemahaman dalam materi Dasar Negara dan Hubungan Konstitusi hingga sebanyak 25 (86, 20\%) siswa.

4. Kemampuan siswa dalam memahami materi yaitu sebelum adanya penelitian siswa yang paham pada materi Dasar Negara dan Hubungan Konstitusi sebanyak 15 siswa atau 51,72\%. Pada putaran I sebanyak 18 atau 62,06\% siswa, pada putaran II sebanyak 25 atau 86,20\% siswa.

\section{Daftar Pustaka}

Arikunto, Suharsimi. 2006. Prosedur Penelitian Suatu Pendekatan Praktik. Jakarta: PT Rineka Cipta.

Arikunto, Suharsimi dkk. 2006. Penelitian Tindakan Kelas. Jakarta: Bumi Aksara.

Budiyanto, Hari dkk. 2009. "Penggunaan Strategi Kartu Indeks Berpasangan untuk Meningkatkan Penguasaan Konsep IPS pada Siswa Kelas IX A SMP Negeri 2 Gatak Sukoharjo". (Program Pendidikan Profesi).Surakarta: FKIP UMS.

Hamalik, Oemar.1998.Kurikulum dan Pembelajaran.Jakarta:Bumi Aksara.

Listyarti, Retno dan Setiadi.2006.Pendidikan Kewarganegaraan Untuk SMK dan MAK Kelas $X . J a k a r t a: P T$ Gelora Aksara.

Malian, Sobirin dan Suparman Marzuki. 2007. Pendidikan Kewarganegaraan dan Hak-hak Asasi Manusia. Yogyakarta: UII Press.

Miles, B. Matthew, dan Michael Huberman. 1992. Analisis Data Kualitatif (Buku Sumber tentang Metode-Metode Baru). Jakarta: UIP.

Moleong. 2004. Metodologi penelitian kualitatif. Bandung: PT Remaja Rosdakarya bandung.

Nawawi, Hadari dan H.M. Martini Hadari. 1992. Instrumen Penelitian Bidang Sosial. Yogyakarta: Gajah Mada University Press. 
Pusat Bahasa Departemen Pendidikan Nasional. 2005. Kamus Besar Bahasa Indonesia Edisi Ketiga. Jakarta: Balai Pustaka.

Sagala, Syaiful. 2003. Konsep dan Makna Pembelajaran. Bandung: Alfabeta.

Silberman. 2001. Active Learning. Yogyakarta: YAPPENDIS.

Suyanto. 2010.'Implementasi Pembelajaran Kooperatif dengan Index Card Match Untuk Meningkatkan Motivasi dan Hasil Belajar IPS Siswa Kelas V SD Negeri 2 Wukirsrawit Jatiyoso Kabupaten Karanganyar Tahun 2009/2010”.( Skripsi, Sarjana-1). Universitas Muhammadiyah Surakarta.

Uno, Hamzah B. 2007. Model Pembelajaran (Menciptakan Proses Belajar Mengajar yang Kreatif dan Efektif). Jakarta: PT Bumi Aksara.

Usman, Moh Uzer dan Lilis Setiawati. 1993. Upaya Optimalisasi Kegiatan Belajar Me-ngajar (Bahan Kajian PKG, MGSB, MGMP). Bandung: PT. Remaja Rosdakarya.

Zaini, Hisyam dkk. 2002. Strategi Pembelajaran Aktif. Yogyakarta: CTSD. 